\title{
The politics of education, fragility and conflict
}

\author{
Clementina Acedo
}

Published online: 7 February 2013

(C) UNESCO IBE 2013

The 2011 EFA Global Monitoring Report, The hidden crisis: Armed conflict and education, is a powerful reminder that conflict continues to affect the lives of millions of the world's most vulnerable people and that it prevents children, young people, and adults from using education as a means of building peace and overcoming other socio-economic and political barriers to full participation in society. But what does the evidence actually say about the relationship between education, fragility and conflict? How can education and curriculum be used as tools to prevent conflict and to build peace? Should conflict-sensitive approaches to education aim at amelioration or transformation?

This special issue, guest-edited by Lene Buchert, offers a sophisticated and profound response to these questions, while also expanding the literature on the relationship between education, fragile situations and conflict. Furthermore, the articles in this issue highlight the need for a comprehensive analysis of these important links. A contextual and "timebound multi-level" analysis, Buchert argues in her Introduction, would address the "ultimate purposes of education policies and programmes, whether they aim to ameliorate or transform existing conditions".

Buchert clarifies the use of the concept of "fragility", a term some have seen as a weak substitute for "pejorative terms such as failed or fragile states" (Smith 2011, cited by Buchert). She agrees with Mosselson, Wheaton, and Frisoli (2009), who urge us to expand our understanding of "fragility", moving from a state-centric definition to one that also considers other factors, ranging from natural disasters and external shocks, to the international system, and to outright violent conflict. Because these factors can affect the lives of individuals and their societies, Buchert argues, they should be kept in focus by anyone developing educational policies and programmes. Thus, the term "fragility" is used in this issue to distinguish between "situations that could potentially erupt into conflict, whether armed or not, and those that are in, or have experienced, conflict".

Buchert also analyzes the role of education in each context tackled in the articles, in light of the relative importance that the contributing authors attach to the economic, political and socio-cultural perspectives or dimensions. She notices that situations of

C. Acedo $(\bowtie)$

UNESCO IBE, P.O. BOX 199, 1211 Geneva 20, Switzerland

e-mail: c.acedo@ibe.unesco.org 
conflict and fragility are most likely to arise when existing inequality leads to grievances over a lack of legitimacy. In such contexts, education plays a crucial role in creating, maintaining or alleviating fragility and conflict.

The articles in this issue are based on original data collected by researchers in a varied group of countries, including Afghanistan, Bolivia, Nepal and Sudan. These four countrybased analyses highlight the dynamics and factors that drive conflict and peace, taking a historical perspective and considering current government attempts at change. The authors analyze how education has been used as a cause of both peace and conflict in these countries; in particular, they look at how education becomes politicized at the expense of its fundamental role of generating knowledge and understanding.

Anders Breidlid analyzes the role that education — and particularly curriculum—plays in conflict, with specific reference to the civil war in Sudan. He discusses the ideological basis of the Sudanese government (GoS) during the civil war, focusing on the role of religion and ethnicity; and the political discourse of the Sudan Peoples' Liberation Movement/Army (SPLM), whose Secretariat of Education produced a secular curriculum during the war. He argues that differences between the Islamist and the secular educational discourses were a reason why many young people in South Sudan took up arms against the Islamist government. A vigorous improvement of the education sector is needed, Breidlid concludes, both to heal conflicts in South Sudan and to give people in the South hope for the future.

Mieke Lopes-Cardozo describes a different socio-political "battlefield", one in a relatively peaceful, stable environment. In Bolivia, the Morales government, in line with its politica del cambio at the national level, has implemented a major restructuring of the governance mechanisms for the teacher education sector. Teachers, seen as agents seeking social justice, are caught in a complex and historically embedded socio-political context of struggles and tensions, strongly influenced by political affiliations, union strategies and institutional cultures. Thus, putting into practice the "new political ideals" of transformation and decolonization has proven to be a complex process.

Tejendra Pherali focuses on schooling in a violent context, by discussing how education was politicized before and after the 2006 peace agreement in Nepal. His analysis reveals that the political intrusion on the education sector before and after the restoration of the multi-party polity in 1990, as well as the violent experiences of teachers and students during the decade-long conflict (1996-2006), have only been slightly reduced since the conflict ended in 2006. Political interference in the education system has continued, with schools becoming de facto power centres, where party cadres exercise their political interests. Pherali concludes that the excessive politicization of the education system, as well as of other state institutions, poses serious threats to any substantial reforms; he calls on development partners to be more critical about both "their own development strategy" and "the state leadership's capacity to negotiate transformation among diverse political forces in the country".

Kaja Borchgrevink examines the transnational links, especially to Pakistan, of Afghan madrasas, which are usually blamed for recruiting Afghan youth into militant groups. In response to this criticism, the Afghan government has initiated a comprehensive reform of the Islamic education sector, which Borchgrevink analyzes in detail. She argues for a broader understanding of religious education in Afghanistan, in the context of a South Asian tradition founded to articulate a modern Islamic alternative to the colonial education system. Its transnational dimensions, Borchgrevink concludes, have implications for the success of the religious curriculum reform within the boundaries of the nation-state.

A fifth article, by Patrick Montjourides, shows how important the nature and quality of data are in efforts to understand and address issues related to conflict. Montjourides argues 
that the lack of "quality" data on education and on human rights violations against children during and after armed conflicts is a failure of the international community, holding back progress in education.

The EFA Global Monitoring Report (UNESCO 2011) identified four other failures: those of protection, provision, reconstruction and peace-building. Montjourides holds that this fifth failure - the lack of quality data - is as important as the other four. He proposes specific steps to ensure higher quality data in terms of completeness and accuracy, timeliness, serviceability and methodological soundness.

The merit of this special issue goes well beyond expanding the literature on the relationship between education, fragility and conflict. The articles in this issue highlight the need for complex understanding and evidence, if we are to fully grasp the role education should play in societal development-a multi-faceted, participatory, long-term process, whose ultimate aim is to empower the people. There is still an urgent need for new international policies for societal development, with a focus on human rights, human dignity, identity and plurality, societal cohesion, and solidarity and societal inclusion. These are all critical areas where education can and should make an important contribution.

\section{References}

Mosselson, J., Wheaton, W., \& Frisoli, P. S. J. (2009). Education and fragility: A synthesis of the literature. Journal of Education for International Development, 4(1), 1-17.

Smith, A. (2011). Education and peacebuilding: From "conflict-analysis" to "conflict transformation"? FriEnt Essay Series, 04, 1-7.

UNESCO (2011). The hidden crisis: Armed conflict and education. EFA Global Monitoring Report. Paris: UNESCO. 